\title{
STUDI PENGAWETAN LARUTAN ENZIM BROMELIN KASAR SECARA FILTRASI DAN PENAMBAHAN NATRIUM BENZOAT
}

\section{(Study Of Preservation Crude Bromelain Enzyme By Filtration And Addition Of Sodium Benzoate)}

\author{
Nandi K. Sukendar ${ }^{1 *}$, Amran Laga ${ }^{1)}$, dan Try Permata Siade ${ }^{1)}$ \\ ${ }^{1 *)}$ Program Studi Ilmu dan Teknologi Pangan Departemen Teknologi Pertanian Universitas Hasanuddin \\ Makassar, Indonesia \\ *email Penulis Korespondensi: nandisukendar@yahoo.com
}

\begin{abstract}
ABSTRAK
Ananas comosus (L) Merr) adalah tanaman yang mengandung enzim bromelin dalam buah, daun dan kulit tetapi lebih banyak di batang. Secara umum, enzim diproduksi dan dipasarkan dalam bentuk bubuk. Namun, memproduksi enzim dalam bentuk bubuk membutuhkan teknologi proses yang tinggi dan biaya yang sangat mahal. Tujuan penelitian ini adalah untuk mengetahui bagaimana menyiapkan enzim bromelin dalam bentuk cair dan teknik preservasi, serta mengetahui kualitas enzim bromelin selama penyimpanan. Penelitian ini dilakukan melalui 3 tahap: 1. Ekstraksi bromelin dari batang nanas, 2. Pelestarian Fisik dan Kimia, 3. Pengamatan penyimpanan enzim. Hasil penelitian menunjukkan bahwa pelestarian enzim bromelin secara fisik dan kimia masih dilakukan aktivitas enzim pada hari ke-32, sedangkan enzim tanpa preservasi tidak menunjukkan aktivitas pada hari ke 24. Enzim Bromelin dengan pengawetan fisik lebih baik daripada pengawetan kimia.
\end{abstract}

Kata Kunci : nanas, bromelin, pengawet enzim, uji aktivitas enzim.

\section{ABSTRACT}

(Ananas comosus (L) Merr) is a plant that contains enzyme bromelin in the fruit, leaf and skin but more in the stem. In general, enzymes are produced and marketed in powder form. However, producing enzymes in powder form requires high process technology and very expensive cost. The purpose of this research were to know how to prepare bromelin enzyme in liquid form and it preservation technique, and to know the quality of bromelin enzyme during storage. This research was conducted through 3 stages: 1. Extraction of bromelin from pineapple stem, 2. Physical and Chemical preservation and 3. Observation of enzyme storage. The results of the study showed that preservation of enzyme bromelin physically and chemically still performed enzyme activity on day 32, while enzyme without preservation did not show activity at day 24. Bromelin enzyme with physical preservation was better than chemical preservation.

Keywords : pineapple, bromelin, enzyme preservation, enzyme activity test.

\section{PENDAHULUAN}

Indonesia memiliki iklim yang sangat cocok untuk potensi perkebunan nanas (Ananas comosus (L) Merr). Tanaman nanas dapat tumbuh dengan baik pada ketinggian 800-1.200 m dpl dengan curah hujan sekitar 1000-1500 mm per tahun.
Suhu yang sesuai untuk budidaya tanaman nanas adalah $23-32^{\circ} \mathrm{C}$. Perkebunan nanas terbesar di Indonesia saat ini berada di Lampung, namun masih banyak daerah lain yang berpotensi untuk perkebunan nanas misalnya Bogor, Riau dan beberapa daerah di Sulawesi. Limbah dari perkebunan nanas seperti daun, batang dan kulit telah banyak 
di olah menghasilkan produk baru. Sala satu potensi pemanfaatan limbah nanas adalah dengan mengekstrak enzim bromelin dari batang (stem) nanas.

Enzim bromelin saat ini telah banyak digunakan baik dalam skala industri besar, menengah, kecil bahkan rumah tangga. Pada industri-industri besar enzim bromelin dimanfaatkan seperti dalam penjernihan bir, pembuatan hard cheese atau dalam bidang farmasi. Sementara pada industri menengah dan rumahan enzim bromelin sering digunakan dalam pengempukan daging karena dapat mendegradasi kolagen daging, sehingga dapat mengempukan daging.

Keberadaan enzim yang beredar di pasaran saat ini diperdagangkan dalam bentuk bubuk dan cair. Produksi dan distribusi enzim dalam bentuk bubuk membutuhkan teknologi proses yang tinggi dan biaya yang sangat mahal. Oleh karena itu perlu dicari alternatif lain pendistribusian enzim konsentrat kasar dalam bentuk larutan yang tidak memerlukan teknologi dan biaya yang tinggi. Teknik pengendalian cemaran mikro organisme dalam larutan konsentrat enzim dapat dilakukan secara fisik dan kimia. Teknik fisik dapat dilakukan dengan filtrasi sementara proses kimiawi umumnya menggunakan asam-asam organik atau garamnya misalnya Natrium benzoat. Efek pengawet kimiawi terhadap kestabilan suatu enzim, misalnya bromelin, di duga dapat terpengaruh. Berdasarkan hal tersebut maka dilakukan penelitian mengenai pengawetan larutan konsentrat enzim bromelin sehingga dapat diperoleh larutan konsentrat enzim bromelin dengan proses yang tergolong mudah namun memiliki masa simpan yang lama.

Pada umumnya enzim diproduksi dan dipasarkan dalam bentuk bubuk. Tetapi untuk menghasilkan enzim dalam bentuk bubuk dibutuhkan teknologi proses yang tinggi dan biaya yang sangat mahal. Karena itu dilakukan alternatif lain untuk memproduksi enzim dalam bentuk cair. Enzim bromelin dalam bentuk cair rentan terhadap cemaran mikroorganisme dan memiliki umur simpan yang tidak tahan lama. Berdasarkan hal tersebut maka dilakukan teknik pengawetan enzim kasar bromelin secara fisik dan kimia serta dilakukan pengamatan uji aktivitas enzim secara kualitatif selama kurang lebih 30 hari.

Tujuan dilakukannya penelitian ini yaitu untuk mengetahui cara preparasi konsentrat enzim bromelin dalam bentuk cair, untuk mengetahui teknik pengawetan konsentrat enzim bromelin dalam bentuk cair., untuk mengetahui mutu dan kualitas enzim bromelin selama penyimpanan.

Kegunaan dari penelitian ini yaitu untuk mengetahui cara pembuatan konsentrat enzim bromelin dalam bentuk cair serta teknik pengawetannya sehingga dapat diaplikasikan pada berbagai produk pangan.

\section{METODOLOGI PENELITIAN}

\subsection{Alat}

Alat-alat yang digunakan pada pengekstraksian enzim bromelin dari batang nanas yaitu, parang, wadah plastik, gunting, blender, kain saring, botol plastik. Alat-alat yang digunakan pada pengawetan enzim secara fisik yaitu alat saring milipore, suntik, botol kaca. Pada pengawetan enzim secara kimia yaitu timbangan analitik, Erlenmeyer, batang pengaduk. Alat-alat yang digunakan pada pengujian aktifitas enzim yaitu erlenmeyer, pipet ukur, balp, termometer, waterbath shaker

\subsection{Bahan}

Bahan-bahan yang digunakan dalam pengekstraksian enzim bromelin dari batang nanas yaitu, air mineral, batang nanas yang telah dipanen buahnya, kertas label, almunium foil, kain saring. Bahanbahan yang digunakan pada pengawetan enzim secara fisik yaitu alkohol $70 \%$, susu full cream. Bahan-bahan yang digunakan dalam pengawetan enzim secara kimia yaitu Natrium benzoat, alumunium foil, tissue. Bahan-bahan yang digunakan pada 
pengujian aktifitas enzim kasar bromelin yaitu susu full cream, kertas label, air.

\subsection{Prosedur Penelitian}

Tahapan prosedur yang dilakukan dalam penelitian ini yaitu tahap pengekstraksian bromelin dari batang nenas, tahap pengawetan secara fisik dan kimia serta tahap pengamatan daya simpan enzim selama 30 hari.

\subsubsection{Preparasi Enzim Bromelin}

Batang nanas dipisahkan dari daundaun yang melekat dan dicuci hingga bersih. Batang nanas dipotong kecil-kecil dan dimasukkan kedalam blender untuk dihaluskan lalu ditimbang. Serat batang nanas yang telah dihaluskan kemudian dibungkus dengan kain saring lalu diperas menggunakan tangan. Filtrat yang diperoleh disaring lagi menggunakan kertas saring lalu dimasukkan kedalam botol plastik. Jumlah cc filtrat yang di peroleh dicatat. Untuk pengujian pertama filtrat diuji kandungan enzim proteolitik dengan memanaskan susu hingga $70^{\circ} \mathrm{C}$ lalu diteteskan filtrat bromelin dan diamati ada tidaknya endapan susu yang terbentuk.

\subsubsection{Pengawetan enzim kasar bromelin secara fisik dan kimia}

Pengawetan secara fisik dilakukan dengan cara enzim kasar bromelin terlebih dahulu disaring menggunakan kertas saring dan dilakukan uji aktivitas enzim. Kemudian enzim hasil penyaringan menggunkan kertas saring difilter lagi menggunakan alat penyaring milipore dengan ukuran $0,45 \mu \mathrm{m}$ dan dilakukan uji aktivitas enzim. setelah itu difilter lagi menggunakan milipore $0,20 \mu \mathrm{m}$ dan dilakukan uji aktivitas enzim. Kemudian enzim kasar bromelin dimasukkan ke dalam botol kaca yang terlebih dahulu di sterilkan menggunkan alkohol $95 \%$ dan disimpan hingga hari ke 32 dan diuji aktivitas enzimnya pada penyimpanan hari ke-0, 6 , 12, 18, 24, dan 32.

Pengawetan secara kimia dilakukan dengan cara enzim kasar bromelin ditambahkan Natrium benzoat sebanyak 0,4\% dari jumlah enzim kasar bromelin. Lalu disimpan selama 32 hari dan dilakukan uji aktivitas enzimnya pada hari ke- $0,6,12,18,24$, dan 32 .

\subsubsection{Pengujian Aktivitas Enzim Bromelin Kasar}

Sampel dari masing-masing perlakuan diamati aktivitas enzimnya untuk selang waktu 6 hari sampai dengan hari penyimpanan ke-32, baik pada pengawetan secara kimiawi maupun secara fisik .

Pengujian aktivitas enzim (pengawetan fisik) dilakukan dengan cara susu cair dipanaskan menggunakan shaker waterbath hingga mencapai suhu $70^{\circ} \mathrm{C}$, kemudian diteteskan filtrate enzim bromelin sebanyak $5 \mathrm{ml}$ dan diamati waktu yang dibutuhkan untuk terjadinya peristiwa flokulasi dan koagulasi dari globular susu. Demikian selanjutnya untuk sampel hari ke12, 24, 30.

Pengujian aktivitas enzim (pengawetan kimiawi) dilakukan dengan cara sebagai berikut. Sejumlah $75 \mathrm{ml}$ susu cair full cream dipanaskan hingga $70^{\circ} \mathrm{C}$ menggunakan shaker water bath. Kemudian di tambahkan $5 \mathrm{ml}$ enzim bromelin kasar dan diamati waktu yang dibutuhkan untuk terjadinya peristiwa flokulasi dan koagulasi dari globular susu. Demikian selanjutnya untuk sampel hari ke-12, 24, 30.

\subsubsection{Pengujian Hidrolisis pada Santan Kelapa \\ Pengujian hidrolisis dilakukan dengan} cara sebagai berikut. Santan kental sebanyak $5 \mathrm{ml}$ dimasukkan ke dalam tabung reaksi, kemudian ditambankan enzim bromelin kasar sebanyak $1 \mathrm{ml}$. Setelah itu di vortex selama 2 menit lalu sampel disimpan di dalam lemari pendingin selama 1 jam, kemudian diamati fraksi yang terbentuk.

\subsubsection{Penyajian Data Hasil Penelitian.}

Data yang diperoleh dari hasil penelitian akan disajikan secara deskriptif 
kuantitatif . Data hasil penelitian tersebut dapat berupa :

1. Data hasil pengamatan aktivitas enzim bromelin kasar hasil filtrasi 0,45 mikron dan 0,2 mikron. (gambar dan tabulasi data)

2. Data hasil pengamatan aktivitas enzim bromelin kasar hasil pengawetan secara kimiawi. (gambar dan tabulasi data)

\section{HASIL DAN PEMBAHASAN}

\subsection{Preparasi Enzim Bromelin}

Batang (stem) nanas yang digunakan dalam penelitian ini berasal dari tanaman nanas yang tumbuh di perkebunan rakyat desa Taripa, kecamatan Pamona Timur, Kabupaten Poso, Sulawesi tengah. Luas perkebunan nanas di desa Taripa yaitu sekitar 5 hektar dan berada di ketinggian $\pm 600 \mathrm{~m}$ di atas permukaan laut dengan suhu rata-rata mencapai $19-25^{\circ} \mathrm{C}$. Tanaman nanas yang telah dicabut di keluarkan buahnya, kemudian dimasukkan ke dalam karung, pengiriman dilakukan menggunakan bis dan membutuhkan waktu sekitar 20 jam.

Batang nanas dipisahkan dari daundaun yang melekat dan dicuci hingga bersih. Batang nanas ditimbang, dipotong-potong dan diblender. Serat batang nanas yang telah dihaluskan kemudian dibungkus dengan kain saring lalu diperas secara manual menggunakan tangan. Filtrat yang diperoleh lalu dimasukkan kedalam botol plastik. Kemudian dilakukan uji aktivitas enzim dengan cara susu dipanaskan hingga $70^{\circ} \mathrm{C}$ kemudian di teteaskan enzim dan diamati hingga terjadinya proses flukoluasi dan koagulasi.

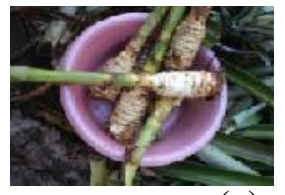

(a)

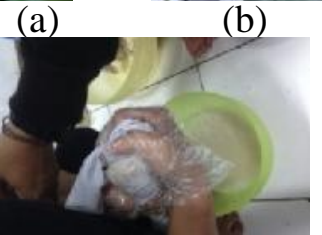

(c)
Gambar 1 Preparasi Enzim Bromelin (a: sortasi dan pembersihan ; b: penghancuran ; c: pemerasan)

\subsection{Pengawetan enzim kasar bromelin secara fisik}

Hasil Pengamatan uji aktivitas enzim selama 32 hari pada pengawetan secara fisik didapatkan hasil seperti pada Gambar 02 .

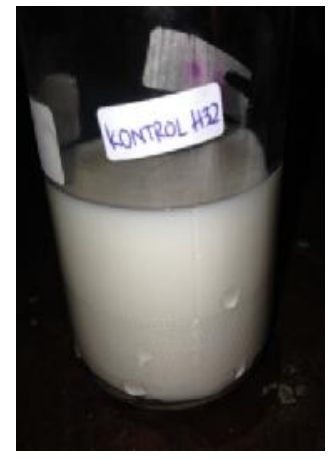

(a)

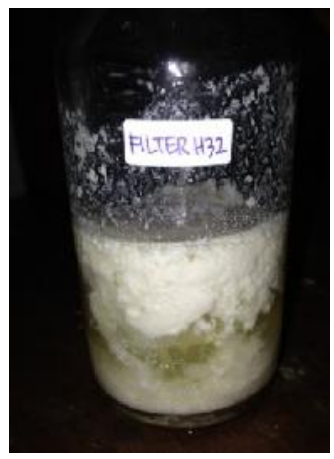

(b)
Gambar 2 Hasil Pengujian Aktivitas Enzim Bromelin Hari ke-32 (a: kontrol ; b: fisik)

Hasil uji aktivitas enzim menunjukkan pada hari ke-18 sudah terlihat perbedaan antara enzim pengawetan secara fisik dengan enzim tanpa pengawetan (kontrol). Perbedaan terlihat lebih signifikan pada hari ke-24 dan hari ke-32 dimana enzim dengan pengawetan secara fisik masih dapat menggumpalkan susu sementara enzim tanpa pengawetan (kontrol) tidak terjadi lagi reaksi flokulasi dan koagulasi. Hal tersebut menunjukkan pengawetan enzim secara fisik dapat mengawetkan enzim bromelin dikarenakan bakteri yang terdapat dalam enzim dapat tersaring melalui proses filterisasi. Hal ini sesuai dengan (Ladle, 2001) yang menyatakan bahwa keefektifan suatu proses sterilisasi dapat ditentukan oleh beban/jumlah mikroorganisme yang tertahan pada alat penyaring.

Pada penelitian ini enzim di filter bertahap menggunakan filter ukuran 0,45 $\mu \mathrm{m}$ kemudian filter berukuran $0,2 \mu \mathrm{m}$. Filterirasi bertahap ini bertujuan untuk melihat apakah ada perbedaan pada hasil filter $0,45 \mu \mathrm{m}$ dengan filter $0,2 \mu \mathrm{m}$. Hasil filterisasi dapat dilihat pada Gambar 6 dan gambar 7. 


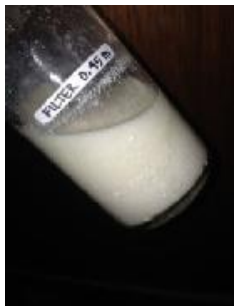

(a)

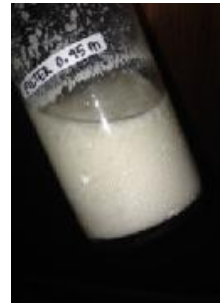

(b)

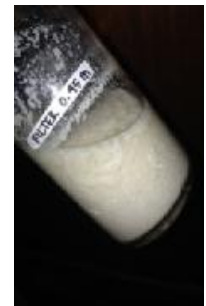

(c)
Gambar 3 Hasil pengujian Aktivitas Enzim

Penyaringan $0,45 \mu \mathrm{m}$ hari ke 0

(a:menit ke-2 ; b:menit ke-5; c: menit ke-10)

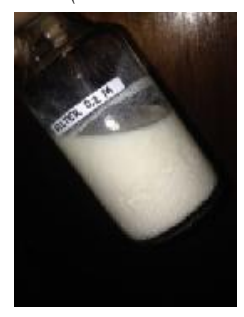

(a)

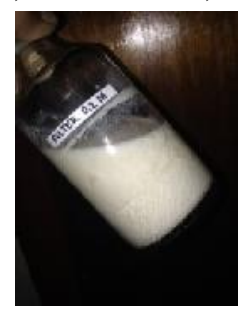

(b)

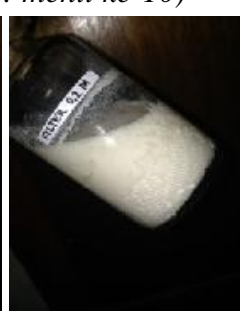

(c)
Gambar 4 asil pengujian Aktivitas Enzim Penyaringan $0,2 \mu \mathrm{m}$ hari ke 0

(a:menit ke-2 ; b:menit ke-5; $c$ : menit ke-10)

Dengan jumlah enzim yang sama yaitu $5 \mathrm{ml}$, dimasukkan ke dalam media susu dengan cc yang sama yaitu $75 \mathrm{ml}$, didapatkan hasil yaitu baik pada penyaringan $0,2 \mu \mathrm{m}$ maupun pada penyaringan $0,45 \mu \mathrm{m}$ terjadi reaksi flokulasi pada menit ke-2 dan reaksi koagulasi pada menit ke-5 yang diteruskan hingga menit ke-10. Tetapi dapat dilihat bahwa enzim dengan penyaringan $0,45 \mu \mathrm{m}$, dengan waktu yang sama dapat menggumpalkan susu lebih banyak dibandingkan dengan enzim penyaringan $0,2 \mu \mathrm{m}$. Hal ini disebabkan karena pada saat enzim difilter dari penyaringan $0,45 \mu \mathrm{m}$ ke penyaringan $0,2 \mu \mathrm{m}$ ada sebagian enzim yang tertahan dan tidak dapat lolos melewati penyaringan. Alat saring milipore tertutup oleh bakteri dan serat-serat nanas yang tertinggal, sehingga permukaan milipore tertahan dan enzim tidak dapat lolos.

\subsection{Pengawetan enzim kasar bromelin secara kimia}

Hasil pengujian aktivitas enzim dengan menggunakan media susu pada pengawetan secara kimia dapat dilihat pada Gambar 5

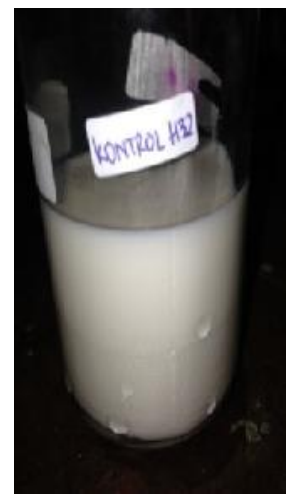

(a)

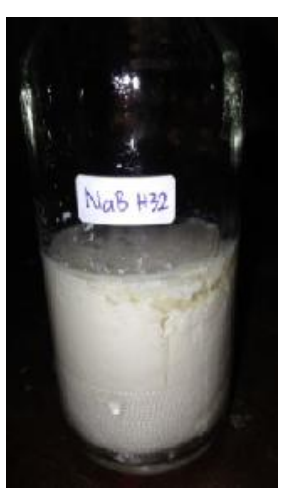

(b)
Gambar 5 Hasil Pengujian Aktivitas Enzim Bromelin Hari ke-32 (a:kontrol ; b:kimia)

Pada hari ke 18 enzim hasil pengawetan kimia, lebih banyak menggumpalkan susu dibanding enzim tanpa pengawetan. Perbedaan Nampak lebih signifikan pada hari ke-24 dan hari ke-32, dimana enzim hasil pengawetan kimia masih terjadi reaksi flokulasi dan koagulasi sementara enzim tanpa pengawetan (kontrol) tidak terjadi reaksi flokulasi dan koagulasi. Hal ini menunjukkan bahwa enzim dengan pengawetan kimia masih dapat bekerja di hari ke-32. Penambahan Natrium benzoat ke dalam enzim bromelin cair dapat menghambat pertumbuhan mikroba yang dapat merusak enzim. Natrium benzoat sebagai anti mikroorganisme berperan dalam mengganggu permeabilitas membran sel dan efektif untuk menghambat pertumbuhan bakteria. . Hal ini sesuai dengan (Afrianti, 2010) yang menyatakan bahwa asam benzoat dan natrium benzoat digunakan untuk menghambat pertumbuhan khamir dan bakteri tetapi kurang efektif untuk kapang.

\subsection{Pengujian Hidrolisis pada Santan Kelapa \\ Hasil pengujian hidrolisis pada santan dapat dilihat pada Gambar 6}




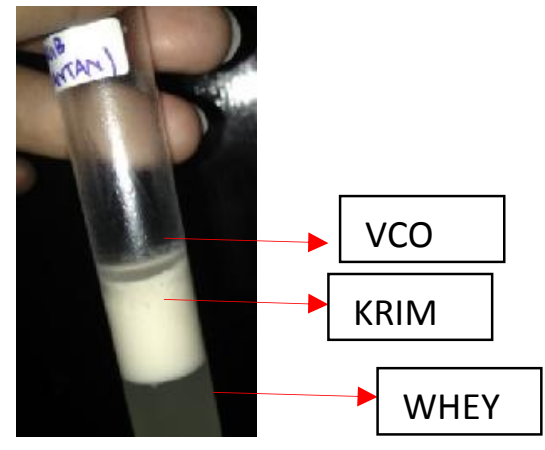

Gambar 6 Hasil Pengujian Hidrolisis Pada Santan

Hasil menunjukkan pada tabung reaksi terdapat VCO pada bagian atas, krim santan pada bagian tengah dan whey pada bagian bawah. Enzim bromelin menyebabkan globula protein pada santan pecah sehingga VCO dapat keluar. Penambahan enzim protease akan memaksimalkan VCO yang dihasilakan, karena enzim protease dapat memecah globula protein pada santan kelapa dengan proses hidrolisis (Khorya, 2015).

\section{KESIMPULAN}

Kesimpulan yang diperoleh dari penelitian ini adalah:

1. Preparasi enzim bromelin dilakukan dengan cara batang nanas dicuci bersih dan dihaluskan dengan blender kemudian diperas menggunakan kain saring. Filtrat yang diperoleh adalah enzim bromelin dalam bentuk cair yang selanjutnya akan diawetkan secara fisik dan kimia.

2. Teknik pengawetan enzim bromelin secara fisik dilakukan dengan cara filterisasi menggunakan alat penyaring milipore dengan ukuran $0,20 \mu \mathrm{m}$. Pengawetan secara kimia dilakukan dengan cara menambahkan Natrium benzoat sebanyak $0,4 \%$ dari jumlah enzim kasar bromelin.

3. Hasil pengujian pengawetan enzim bromelin adalah baik pengawetan secara fisik maupun kimia masih menunjukkan aktivitas enzim pada hari ke-32, sedangkan enzim tanpa pengawetan sudah tidak menunjukkan aktivitas di hari ke-24. Didapatkan pula hasil bahwa enzim bromelin dengan pengawetan fisik lebih baik dibandingkan dengan enzim bromelin pengawetan kimia.

\section{DAFTAR PUSTAKA}

Afrianti. (2010). Pengawet Makanan Alami dan Sintetis. Bandung: Alfabeta.

Khorya. (2015). Pemanfaatan Enzim Protease dari Tanaman Biduri Untuk Pengolahan Makanan. Sains Dan Teknologi, 1(1), 32-37.

Ladle. (2001). Pharmaceutical Technology Fundamental Pharmaceutics. USA: Burgess Publishing Company. 